experiments', and his greatest original contribution to science was his magnificent discovery and proof that the earth is a colossal natural magnet in itself. Dr. Kramer's paper contains many extracts from the various writers on magnetism, and should prove of wide interest.

\section{Goethe's Scientific Works}

A special issue of the Berlin journal, Forschungen und Fortschritte, dated March 1932, includes thirtynine pages devoted to a series of articles by more than thirty authorities dealing chiefly with Goothe's influence as a man of science. The subjects covered include mathematics, the theory of colours and optics, chemistry, geology, meteorology, botany, zoology, and anatomy, together with an appreciation of the Goethe Museum at Frankfurt. In the restricted space at the disposal of each author, it has only been possible to deal very briefly with what are often abstruse and involved matters of history, but, nevertheless, these articles should prove a very useful guide to those who propose to take up the study of Goethe's scientific works. The modern critic of Goethe's central idea of the unity of plan has little to add to Schiller's acute observation of 1794, quoted by Prof. O. Abel-_" Das ist keine Erfahrung, das ist eine Idee ", and Goethe's response- - "Das kann mir sehr lieb sein, dass ich Ideen habe, ohne es zu wissen, und sie sogar mit eigenen Augen sehe ", is an admirable epitome of his own attitude towards the central idea.

\section{Source of 'Nagana' in South Africa}

Dr. E. WARren, director of the Natal Museum, has reported, according to a message in the Times of March 10, that experiments carried out by $\mathrm{Mr}$. Davidson, an independent naturalist, " completely destroy the theory at present accepted about the reservoir of infection from which the tsetse fly transmits the widespread cattle disease known as Nagana". It is generally accepted-and has, in fact, been repeatedly proved-that the blood of game animals harbours trypanosomes which, when conveyed to domestic animals by the tsetse fly, give rise to the serious and often fatal diseases which are grouped under the term 'nagana'. Mr. Davidson now claims to have shown that the trypanosome responsible is derived from the latex of certain plants " on which the tsetse fly normally feeds ". Further information on these observations (which appear to have satisfied Dr. Warren, by whom they have been " carefully checked") will be awaited with much interest. It is well known that leptomonad-like flagellates are common in the latex of Euphorbia and other plants, being transmitted from one plant to another by certain plant-sucking bugs; but no evidence has as yet been published that these organisms can cause disease in vertebrates; and up to the present time no trypanosome has ever been discovered in a plant. The tsetse fly has occasionally been observed to plunge its proboscis into certain fruits, but in the past it has seemed very doubtful if these constitute a regular source of food supply.

No. 3255, VoL. 129]

\section{Chester Roman Amphitheatre Appeal}

DeTERMINed efforts are to be made to save the Roman amphitheatre at Chester, which is threatened by the proposal to construct a by-pass road that, on the lines contemplated at present, would pass through the centre of the arena. The Council of the Chester and North Wales Archæological Society has issued a statement in which it is pointed out that even if the road could be constructed without damage to the remains, which is doubtful, it would put excavation in the future out of the question, while it is inevitable that the northern area adjoining the road would be developed for building purposes, and also made inaccessible. The Office of Works, which has been approached in the matter, views with approval the scheme to save the amphitheatre, which is the most considerable in Great Britain. The Office of Works would itself undertake the cost of excavation and be responsible for the future maintenance of the monument if the site was placed in its keeping. The cost of diverting the by-pass road to avoid the amphitheatre is estimated at a sum of $£ 8000$. The Council of the Archæological Society, therefore, appeals to the people of Chester, and of Great Britain, for a sum sufficient to enable this monument to be preserved. A stay of three months has been granted to afford an opportunity for the amount required to be raised.

\section{Metallurgical Literature}

THE annual general meeting of the Institute of Metals was held on March 9 and 10, and the incoming president, Sir Henry Fowler, delivered his addresis on the first day. Referring to the literature of metallurgy forty years ago, Sir Henry remarked that it was very meagre in Great Britain, especially as regards nonferrous metals; and that possibly this lack was in part responsible for the formation of the Institute of Metals, for among its original objects was the publication of a journal containing original papers and abstracts. Abstracts appeared for the first time in the second volume of the Journal of the Institute, occupying 41 pages. In the last issue of the Journal in which they were incorporated, they occupied (with index) 436 pages. Now that the Journal is being published monthly, it is hoped that abstracts will be available within six weeks of the original publication of important papers. Sir Henry stated that more than a thousand periodicals, in about twenty languages, are searched systematically by a band of more than thirty qualified abstractors, who provided in the past twelve months more than four thousand abstracts. The magnitude of this undertaking is probably unique as the work of a single institution.

\section{Practical Applications of Fundamental Research}

Sir Henry Fowler went on to speak of the importance of fundamental research and of the 'marrying-up' of research with its practical applications. There is nowadays unquestionably much better understanding between the research worker in metallurgy and the practical engineer, due to the 
increased facilities for metallurgical education and to the growing importance of metallurgy. Difficulties are still met, however, when the research worker neglects to express himself simply and intelligibly, or the practical man may be unduly conservative as regards new ideas. Sir Henry quoted one example from his own experience in which prejudice was likely to obstruct the application of research in practice. In 1922 he heard incidentally that a small percentage of copper increased the corrosion-resisting properties of steel. Owing to the story, apparently, that if a puddler wished to get a fellow-worker into trouble, he threw a penny into the puddling furnace, it was difficult to get the material made. Finally, Sir Robert Hadfield accepted the order for a small cast of 'copper-bearing steel'. The metal was required for the smoke-box and ash-pan plates of locomotives, and it took a further six or seven years to show that better results were obtained than with ordinary steel, thus emphasising another point, that the practical test of a discovery should be started as quickly as possible without awaiting its full development. The research associations are invaluable in bringing together those directly engaged in industry and those conducting research.

\section{Land Utilisation Survey}

The Land Utilisation Survey of Britain organised by the London School of Economics and the Geographical Association, under the direction of Dr. L. Dudley Stamp, reports considerable progress during its first year. A general report on the work is given in the Bulletin of the Survey for February. After fifteen months' work, four counties in England and one in Scotland are completely finished and another eight counties are on the verge of completion. Of the 22,000 quarter-sheets of the 6-inch map of Great Britain, 3670 have been finished. This is good progress, when it is borne in mind that the work had to be organised from the start in every county and is entirely on a voluntary basis. The completed sheets are being reduced to a l-inch scale, and will then be printed in seven colours and issued by the Ordnance Survey. The numbering of these sheets will be on the basis of the popular edition of the 1-inch map. Sheet 114 (Windsor) is to be produced as an experimental sheet. While work is proceeding rapidly, in parts of the country, particularly in some of the counties of northern England, there are several areas in which little has yet been done. These blank areas include Gloucestershire, Essex, Huntingdon, several Welsh counties, the North Riding of Yorkshire, much of Northumberland, south-west Scotland, and large areas in the central and western Highlands. For these and other regions workers are still required.

\section{Natural History in Church Records}

I $T$ is strange from what odd quarters knowledge about the history of animal life may be gathered. This was apparently also the opinion of the vicar of Ridge, who refused permission to examine his parish books, on the ground that he found it difficult to conceive that payments for 'vermin' by parish No. 3255, VoL. 129] authorities could be of interest to anyone. For tunately no other refusal was met by Charles Oldham, and the results of his searches amongst church. wardens' records in Hertfordshire are some odd contributions to the history of vermin (Trans. Hertfords. Nat. Hist. Soc., vol. 19, pt. 2; 1931). Sparrows, which had increased enormously in num. bers because of the intensive cultivation of cereals, had a price upon their heads, and a record (Aldbury) of 1720 reads, " $\mathrm{Pd}$ for 6 Doz. of Sparrows heads ...1s."; and yet, at the same period, others were deliberately encouraging sparrows to multiply by setting up for their use curious receptacles, 'sparrow. pots', from which the young sparrows were taken for food. The most telling of all the records are those relating to the prices paid for the destruction of polecats. In 1721, at Chipping Barnet, $4 d$. was paid for two, in 1723 "for 4 Polecatt . . . 4s." was paid at East Barnet; these records, giving the extreme range of prices, indicate a common and almost worthless creature, and contrast with the demand in Scotland, where at one stage the price of a furrier's dozen of polecats reached $45 \mathrm{~s}$. Long before that time, in the mid-nineteenth century, when fur value of the polecat had made its pelt desirable, the pole. cats of Hertfordshire had been exterminated as 'vermin'

\section{Irish Forests}

THE opinion was widely held amongst Irish and English historians of the eighteenth and nineteenth centuries that Ireland was densely wooded down to the last five hundred years, and that the disappearance of the native forests was chiefly due to their exploitation by English adventurers, and the effects of the wars and disturbances during Elizabethan and Crom. wellian times. According to A. C. Forbes in his paper on "Some Legendary and Historical References to Irish Forests and their Significance", read before the Royal Irish Academy on Feb. 22, a review of the various authors who were responsible for this conclu. sion has shown that none can be considered sufficiently acquainted with Ireland to have been an authority on the subject. State papers and other documents indicate that the arrival of the Normans in the twelfth century found Ireland much as it is to-day. A point of considerable interest is the exact position of forest land under the forest laws of the Normans. This forest land was the waste or unenclosed portion of the country, and had no direct connexion with woods or timber trees. Two Irish deafforestation charters of the thirteenth century are in existence, but no record can be found of any proceeding for creating a forest, and $\mathrm{Mr}$. Forbes advanced the theory that the wastes of both Ireland and England were normally afforested or subject to forest laws at a remote period, and that these laws were gradually removed by deafforestation, for which money payments were frequently made to the Crown. Manwood's "Lawes of the Forest" is a doubtful guide on this subject. A further point of interest is the existence of Pinus sylvestris in the Irish flora during the historic period. While the pine was a dominant species when the older 